Original Research Article

\title{
Study of effect of Nigella sativa on prevention of nephrotoxicity induced by colistin in experimental animals
}

\author{
M. Azmat Rana1, M. Nadeem Arshad ${ }^{1 *}$, Salman Shafi Siddiqui' ${ }^{2}$, M. Nasiruddin ${ }^{3}$
}

${ }^{1}$ Department of Pharmacology, Katihar Medical College,

Katihar, Bihar, India

2Department of Physiology, Muzaffrangar Medical College and Hospital, Uttar Pradesh, India

${ }^{3}$ Department of Pharmacology, AMU, Aligarh, Uttar Pradesh, India

Received: 06 December 2018 Accepted: 29 December 2018

\section{*Correspondence to: \\ Dr. M. Nadeem Arshad, Email: drnarshad786@ gmail.com}

Copyright: (C) the author(s), publisher and licensee Medip Academy. This is an openaccess article distributed under the terms of the Creative Commons Attribution NonCommercial License, which permits unrestricted noncommercial use, distribution, and reproduction in any medium, provided the original work is properly cited.

\begin{abstract}
Background: Nigella sativa, a widely used medicinal plant throughout the world belongs to family ranunculaceae. Its Seeds and oil have a long history of folklore usage in various traditional systems of medicines and food. This study was performed to evaluate the protective effect of Nigella sativa oil (NSO) on kidney when simultaneously given with colistin sulfate (CS) which induces tubular damage in rats.

Methods: Animals were treated for 7 days: Group I ( $n=6)$ with normal saline and CMC, Group II, III and IV with $300.000 I U / \mathrm{kg} /$ day of CS $(\mathrm{n}=6)$. Group III and Group IV with NSO at the dose of 1 and $2 \mathrm{ml} / \mathrm{kg}$ per orum prior to CS administration. All the animals were sacrificed on $8^{\text {th }}$ day. Afterwards, the plasma creatinine ( $\mathrm{pCr}$ ), blood urea, renal tissue level of malondialdehyde (MDA), reduced glutathione (GSH) and renal histology were performed.

Results: Colistin sulfate induced tubular damage, increased the plasma creatinine $(\mathrm{pCr})$, blood urea and MDA levels and decreased the reduced glutathione (GSH). However, simultaneous treatment with Nigella sativa oil at the dose of $1 \mathrm{ml} / \mathrm{kg}$ and $2 \mathrm{ml} / \mathrm{kg}$ for one week produced dose dependant improvement in tubular damage and reduced the biochemical alteration.

Conclusions: It could be concluded that, Colistin sulfate induced nephrotoxicity is ameliorated by NS oil especially in higher dose of $(2 \mathrm{ml} / \mathrm{kg})$. This nephroprotective effect is ascribed to free radical scavenging and potent antioxidant activity in Nigella sativa.
\end{abstract}

Keywords: Colistin, Nephrotoxicity, Nigella sativa oil, Oxidative stress

\section{INTRODUCTION}

Colistin, a polymyxin $\mathrm{E}$, is an old polypeptide cationic antibiotic. First introduced in 1952, since then it has been mainly used to treat gram-negative bacterial infections. ${ }^{1,2}$ However, in the previous two decades, its use has been discontinued due to its frequent nephrotoxic side effect. ${ }^{1-3}$ But recently due to the emergence of multidrug-resistant gram-negative bacterial infections, colistin has the potential to be reintroduced into clinical practice. ${ }^{4}$ And therefore the side effect of nephrotoxicity associated with colistin have begun to be observed again. The incidence of nephrotoxicity with colistin varies in different publication but as high as $53.5 \%$ has been observed at currently recommended dosage regimen in clinical practice. ${ }^{5}$ The nephrotoxic side effect of colistin is dose-dependent and can be reversible upon discontinuation. ${ }^{6,7}$ Although, various mechanism of colistin nephrotoxicity has been suggested none is yet fully established. Recent animal 
studies suggest that oxidative stress has a role in colistininduced renal toxicity. This oxidative stress, in turn, leads to increased cell membrane permeability, cell swelling, and lysis associated with an increased influx of cations, anions, and water; and, finally, apoptosis has been implicated. ${ }^{8}$ Oxidative stress involving generation of reactive oxygen species via mitochondria have been shown to initiate renal cell apoptosis, ultimately leading to renal dysfunction. ${ }^{9}$ Therefore antioxidants may play a key role in amelioration of colistin-induced nephrotoxicity. Recently, exploration of natural sources for antioxidants has been intensified for the treatment of various conditions related to oxidative stress injury. ${ }^{10}$

Nigella sativa is a grassy plant belonging to the family Ranunculaceae with green to blue flowers and small black seeds. Nigella sativa seeds contain numerous biologically active components/phytochemicals which exhibit a wide spectrum of biological activities such as antioxidant, antidiabetic, anti-inflammatory, nephroprotective and hepatoprotective properties. ${ }^{11,12} \mathrm{NS}$ oil (NSO) contains fixed oil (30\%) and volatile oil ( $0.5 \%)$, proteins, alkaloids, and saponins. Thymoquinone, the principal active ingredient of NS oil, possesses antioxidant activity to scavenge free radicals and to protect the cell against oxidative damage. ${ }^{13-15}$ In addition, NSO is an important source of polyunsaturated fatty acids (PUFA) that contains omega ()-3PUFA and -6 PUFA in the recommended optimal dietary intake ratio of 1:4. ${ }^{16,17}$ Consumption of -3 and -6 essential fatty acid in the right proportion has been found to suppress the pathogenesis of many diseases. ${ }^{18,19}$ The aim of our study was to further confirm the role of oxidative stress in the pathogenesis of nephrotoxicity secondary to colistin treatment. The other aim of the study was to evaluate the role of Nigella sativa oil in preventing colistin-induced nephrotoxicity.

\section{METHODS}

\section{Chemical products}

N. sativa oil was obtained from Mohammedia Products, Red Hills, Nampally, Hyderabad, India. CS was obtained from Sigma-Aldrich Chemical Corp., St. Louis, MO, USA. Diagnostic kits for serum creatinine, blood urea, and urine sugar were purchased from Span Diagnostic Ltd. Hyderabad, India. All other chemicals were of analytical grade and were purchased from standard commercial suppliers.

\section{Experimental animals}

Healthy adult albino rats weighing between 150 and $200 \mathrm{~g}$ of either sex were procured from the central animal house of the Katihar Medical College, Katihar. The animals were housed and maintained in laboratory conditions according to the Committee for purpose of control and supervision of experiment on Animals (CPCSEA) guidelines. They were supplied with drinking water ad libitum and a pellet diet. Rats were acclimatized for one week prior to experimentation in the laboratory conditions. Ethical clearance for the study was obtained from the Institutional Animal Ethics Committee.

\section{Experimental design}

Following seven days of acclimatization period, twenty four rats were randomly divided into four groups, with six rats each and placed into separate cages. All rats had access to pellet diet and water ad libitum throughout the experiment. Group I served as the vehicle control group and received normal saline intraperitoneally $(1 \mathrm{~mL} / \mathrm{kg})$ and $0.5 \% \mathrm{CMC}$ per orum daily $(1 \mathrm{~mL} / \mathrm{kg})$.

Group II served as the negative control group and received $0.5 \%$ CMC per orum daily ( $1 \mathrm{~mL} / \mathrm{kg}$ ). Group III (NSOCS1) and Group IV (NSOCS2) were the test groups that received the Nigella sativa oil at the dose of $1 \mathrm{ml} / \mathrm{kg}$ and $2 \mathrm{ml} / \mathrm{kg}$ per orum daily. Group II (CS), Group III (NSOCS1) and Group IV (NSOCS2) were given 300,000IU/kg. ${ }^{19}$ colistin per day for 7 days intraperitoneally (i.p.). NSO was given $1 \mathrm{~h}$ prior to the administration of colistin in the treatment groups. Following the last dose of treatment, the animals were housed individually in separate metabolic cages to collect the 24-h urine. Twenty-four hours after the last dosing, i.e. on the 8th day, the rats were anaesthetized with $90 \mathrm{mg} / \mathrm{kg}$ of ketamine and $10 \mathrm{mg} / \mathrm{kg}$ of xylazine and midline incision was performed. Blood samples were collected by cardiac puncture. Serum was separated by centrifuging the blood at $2500 \mathrm{rpm}(1500 \mathrm{~g})$ for $10 \mathrm{~min}$ and stored. Kidneys were dissected out and weighed. One kidney was preserved in $10 \%$ formalin for histopathological examination and the other kidney was cut into small pieces and homogenized. Homogenization was performed at $5000 \mathrm{rpm}(3000 \mathrm{~g})$ in potassium-phosphate buffer $(\mathrm{pH} 7.36,0.1 \mathrm{M})$ and the supernatant was taken out for biochemical analysis for assessment of oxidative stress and antioxidant activity. For the estimation of reduced glutathione (GSH), $1 \mathrm{~mL}$ of homogenate of each rat as such was stored separately. All the samples were labelled properly and stored at $-20^{\circ} \mathrm{C}$ for further analysis.

\section{Biochemical assays}

Serum urea concentration was estimated by DAM method, while serum creatinine and urine creatinine by alkaline picrate method and urine glucose levels by GOD-POD method using diagnostic kits purchased from Span Diagnostics, Hyderabad, India.

Creatinine clearance $(\mathrm{CrCl})$ was calculated using the following formula:

\section{$\mathrm{CrCl}(\mathrm{mL} / \mathrm{min} / 100 \mathrm{~g}$ body weight $)$}

$$
=\frac{\text { Urine creatinine } \times 24-\mathrm{h} \text { urine volume } \times 100}{\text { Serum creatinine } \times(24 \times 60) \times \text { body weight }}
$$

For estimation of oxidative stress, Malonyldialdehyde 
(MDA) level was determined by method described by Buege and Aust. ${ }^{20}$ While for assaying antioxidant markers, catalase activity was performed. The level of catalase was estimated by method described by Sinha et al. ${ }^{21}$ Reduced GSH level estimation was performed according to the method of Ellman. ${ }^{22}$

\section{Histopathological examinations}

For light microscopic examination, formalin preserved kidneys were removed from the control and tested groups. Then they were embedded in paraffin and and 5-6 $\mu \mathrm{m}$ sections were cut using a rotary microtome and stained with hematoxylin and eosin (HandE).

All sections were evaluated for the degree of glomerular congestion, mononuclear cell infiltration, tubular necrosis and tubular hyaline casts.

\section{Statistical analysis}

Data of the study have been expressed as mean \pm standard error of mean (SEM). The Statistically significant differences were determined by one-way analysis of variance (ANOVA) followed by the post hoc Dunnets test for multiple comparisons. Probability values $(\mathrm{P})<0.05$ were considered to be statistically significant.

\section{RESULTS}

\section{Effect on physical parameters}

The physical parameters studied after seven days of oral treatment were percentage change in body weight, kidney weight per $100 \mathrm{~g}$ of body weight, kidney volume and urine volume. Administration of a daily i.p. injection of CMS $300,000 \mathrm{IU} / \mathrm{kg}$ body weight in the negative control group caused a decrease in body weight, urine volume and an increase in kidney weight, kidney volume as shown in Table 1. The changes were statistically significant ( $\mathrm{P}$ $<0.001)$ as compared with the normal control group. Administration of NS oil at doses of $1 \mathrm{ml}$ and $2 \mathrm{ml} / \mathrm{kg}$ for seven days caused a dose-dependent reversal. There was a lower reduction in body weight in test groups as compared with the negative control group. The increase in kidney weight, kidney volume and decrease in urine volume in NS oil treated groups was also lower as compared with the negative control group. However, the increase in kidney volume in NS oil treated groups was significantly (P $<0.05)$ less as compared with the negative control group.

Table 1: Effect of Nigella sativa oil on alteration of physical parameters.

\begin{tabular}{|llllll|}
\hline G. no & Groups & $\begin{array}{l}\text { \% Change in body } \\
\text { weight }\end{array}$ & $\begin{array}{l}\text { Kidney weight per } \\
100 \mathrm{~g} \mathrm{~B} . \text { wt }(\mathrm{g})\end{array}$ & $\begin{array}{l}\text { Kidney volume } \\
(\mathrm{ml})\end{array}$ & $\begin{array}{l}\text { Urine volume/day } \\
(\mathrm{ml})\end{array}$ \\
\hline I. & Vehicle control & $(+) 3.76 \pm 0.54$ & $0.40 \pm 0.017$ & $0.78 \pm 0.030$ & $9.83 \pm 0.77$ \\
\hline II. & Negative control & $(-) 9.51 \pm 0.47^{* * *}$ & $0.60 \pm 0.007^{* * *}$ & $1.21 \pm 0.016^{* * *}$ & $18.75 \pm 1.13^{* * *}$ \\
\hline III. & NSO1 & $(-) 5.15 \pm 1.46$ & $0.53 \pm 0.017^{* *}$ & $1.08 \pm 0.030^{* *}$ & $14.33 \pm 0.66^{* * *}$ \\
\hline IV. & NSO2 & $(-) 4.98 \pm 0.75$ & $0.48 \pm 0.014^{* * *}$ & $0.95 \pm 0.022^{* * *}$ & $12.00 \pm 0.34$ \\
\hline
\end{tabular}

NSO: Nigella sativa oil at $1 \mathrm{ml} / \mathrm{kg}$ and $2 \mathrm{ml} / \mathrm{kg}$ doses; data were expressed in mean $\pm \mathrm{SEM}(\mathrm{n}=6$ rats/group). The negative control group was compared with the normal control group and all other groups were compared with the negative control group, $* \mathrm{P}<0.05$, $* * \mathrm{P}<0.01$ and $* * * \mathrm{P}<0.001$ were considered significant

Table 2: Effect of Nigella sativa oil on alteration of biochemical parameters.

\begin{tabular}{|lllll|}
\hline S. No. & Groups & $\begin{array}{l}\text { Blood urea } \\
(\mathbf{m g} / \mathbf{d l})\end{array}$ & $\begin{array}{l}\text { Urine glucose } \\
(\mathbf{m g} / \mathbf{d l})\end{array}$ & $\begin{array}{l}\text { Creatinine clearance } \\
(\mathbf{m l} / \mathbf{m i n} / \mathbf{1 0 0 g} \text { B W) }\end{array}$ \\
\hline I. & Vehicle control & $55.8 \pm 3.92$ & $15.72 \pm 1.17$ & $0.624 \pm 0.012$ \\
\hline II. & Negative control & $116.00 \pm 14.45^{\text {*** }}$ & $50.53 \pm 5.19^{* * *}$ & $0.284 \pm 0.016^{* * *}$ \\
\hline III. & NSO1 & $88.68 \pm 2.45^{\text {*** }}$ & $38.65 \pm 5.32^{\text {** }}$ & $0.347 \pm 0.012^{* *}$ \\
\hline IV. & NSO2 & $68.18 \pm 4.57^{* * *}$ & $27.73 \pm 3.70^{\text {*** }}$ & $0.452 \pm 0.012^{\text {*** }}$ \\
\hline
\end{tabular}

NSO: Nigella sativa oil at $1 \mathrm{ml} / \mathrm{kg}$ and $2 \mathrm{ml} / \mathrm{kg}$ doses; data were expressed in mean \pm SEM ( $\mathrm{n}=6$ rats/group). The negative control group was compared with the normal control group and all other groups were compared with the negative control group, $* P<0.05, * * P<0.01$ and $* * * P<0.001$ were considered significant

\section{Effect on kidney functions}

Blood urea, urine glucose and creatinine clearance were taken as markers of kidney function. In the negative control group, animals treated with daily i.p. injection of CS $300,000 I U / k g$ body weight, the levels of blood urea, serum creatinine and urine glucose were significantly elevated ( $P<0.001)$ while creatinine clearance was significantly decreased $(\mathrm{P}<0.001)$. Data are shown in Table 2. Administration of NS oil at doses of $1 \mathrm{ml}$ and $2 \mathrm{ml} / \mathrm{kg}$ for seven days caused dose-dependent protection against CMS-induced nephrotoxicity. The rise in blood 
urea, serum creatinine, and urine glucose was less compared with that in the negative control group. There was an improvement in creatinine clearance, i.e. the reduction in creatinine clearance was lesser in the test groups compared with the negative control group. Changes in the above parameters in the NS oil at doses of $1 \mathrm{ml}$ and $2 \mathrm{ml} / \mathrm{kg}$ treated groups were statistically significant $(\mathrm{P}$ $<0.01)$ compared with the negative control group.

\section{Effect on oxidative stress and antioxidant defense parameters}

For oxidative stress, malonyldialdehyde (MDA) test and for antioxidant defense status, catalase and reduced GSH test were performed on homogenized kidney tissue. CMS administration significantly elevated the MDA ( $\mathrm{P}<0.001)$ level and decreased the catalase $(\mathrm{P}<0.001)$ and GSH $(\mathrm{P}<0.001)$ activity, as shown in Table 3 . Administration of NS oil at doses of $1 \mathrm{ml}$ and $2 \mathrm{ml} / \mathrm{kg}$ for seven days caused significant change in the levels of MDA $(\mathrm{P}<0.01)$, catalase $(\mathrm{P}<0.01)$ and GSH $(\mathrm{P}<0.01)$ in the test groups compared with the control group.

\section{Histopathological examination}

Light microscopic examination of the kidney section of the normal control group (Figure 1A) showed normal glomerulus and tubules with normal architecture. However, the kidney sections of the CS treated negative control group (Figure 1B), showed slight tubular dilatation, interstitial edema and inflammatory cell infiltration. Though treatment with NS oil at the doses of $1 \mathrm{ml} / \mathrm{kg}$ showed lesser damage as compared with the negative control group with respect to tubular dialatation, infiltration, interstitial cell edema and congestion (Figure 1C). But treatment with NS oil at the dose of $2 \mathrm{ml} / \mathrm{kg}$ completely prevented the damage and tissue section is comparable to normal control (Figure 1D).

Table 3: Effect of Nigella sativa oil on in-vivo oxidative and antioxidant system.

\begin{tabular}{|lllll|}
\hline S. No. & Groups & $\begin{array}{l}\text { MDA (nmoles/g } \\
\text { wet tissue wt.) }\end{array}$ & $\begin{array}{l}\text { Catalase (nmoles } \\
\text { H2O2consumed/min/mg protein) }\end{array}$ & $\begin{array}{l}\text { GSH (nmoles/mg } \\
\text { protein) }\end{array}$ \\
\hline I. & Vehicle control & $58.69 \pm 1.94$ & $124.81 \pm 2.20$ & $20.62 \pm 0.25$ \\
\hline II. & Negative control & $117.19 \pm 1.83^{* * *}$ & $75.09 \pm 2.06^{* * *}$ & $10.16 \pm 0.22^{\text {*** }}$ \\
\hline III. & NSO1 & $99.45 \pm 2.27^{* * *}$ & $95.63 \pm 1.55^{\text {** }}$ & $12.11 \pm 0.14^{* * *}$ \\
\hline IV. & NSO2 & $81.37 \pm 1.43^{* * *}$ & $116.73 \pm 1.94^{* * *}$ & $14.65 \pm 0.19^{* * *}$ \\
\hline
\end{tabular}

NSO: Nigella sativa oil at $1 \mathrm{ml} / \mathrm{kg}$ and $2 \mathrm{ml} / \mathrm{kg}$ doses; data were expressed in mean \pm SEM ( $\mathrm{n}=6$ rats/group). The negative control group was compared with the normal control group and all other groups were compared with the negative control group, $* \mathrm{P}<0.05$, ** $\mathrm{P}<0.01$ and $* * * \mathrm{P}<0.001$ were considered significant

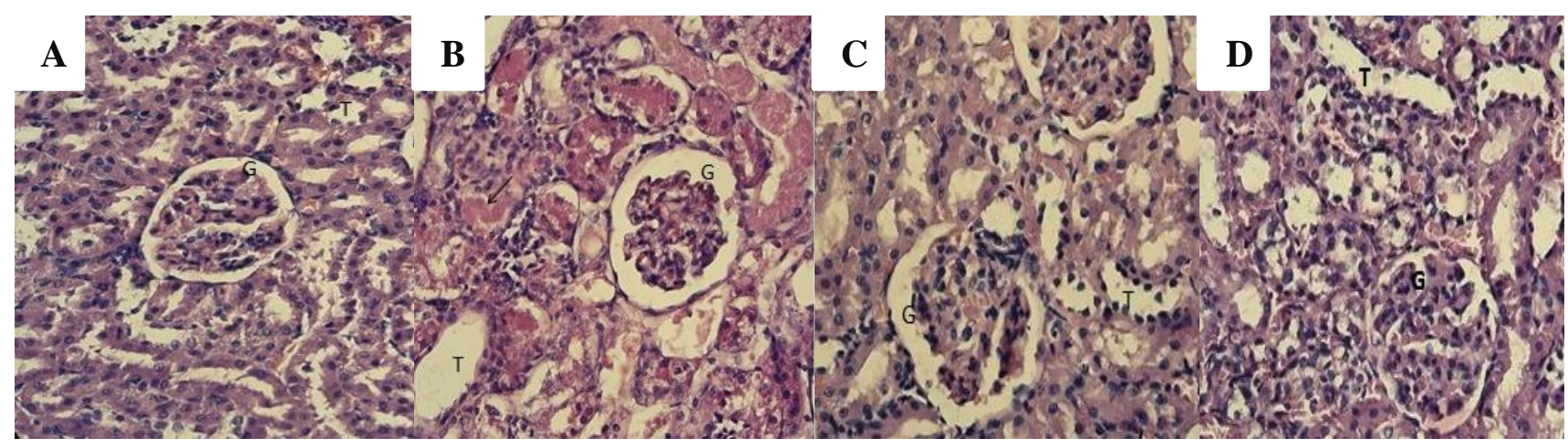

Figure 1: Rat kidney tissue section. (A) Histology of the kidney tissue in the control group (Group I) showing normal architecture of the glomerulus and tubules $($ HandE $\times 400)$. (B) Colistin only treated negative control group

(Group II) showing mononuclear cell infiltration, glomerular congestion, tubular necrosis and hyaline casts

(HandE $\times$ 400). (C) Colistin plus NSO1 treated group (Group III) showing mild mononuclear cell infiltration with mild glomerular congestion (HandE $\times 400$ ). (D) Colistin plus NSO2 treated group (Group VI) showing improvement in the architecture resembling the control group (HandE $\times 400)$.

\section{DISCUSSION}

Colistin is an old polypeptide antibiotic used against
Gram-negative bacterial infections in clinical practice. Previously, its use was declined because of its renal toxic effect. But, recently due to the development of multidrug- 
resistant bacterial infections it has been reintroduced.

The pathogenesis of colistin associated renal toxicity has not been understood yet in detail, and currently no effective therapeutic or prophylactic drug is available. Therefore, in the current study, we have tried to elucidate the mechanism of colistin induced renal toxicity and preventive approach for the treatment of colistin induced renal toxicity. The administration of $300.000 \mathrm{IU} / \mathrm{kg} / \mathrm{day}$ of CMS for 7 days in rats produced a significant alteration in physical parameters i.e. decrease in body weight and increase in kidney weight and urine volume (Table 1). Increased catabolism and decreased food intake might be the reason for decreased body weight. The increase in normalized kidney weight with respect to the body weight of rats of the colistin treated negative control group resulted from the edema due to drug-induced pathological changes in the tubules. The significant decrease in urine volume per day in the colistin treated negative control group compared with the normal control group confirms the colistin induced oliguric acute renal failure. Biochemical markers of serum and urine confirmed that colistin administration for seven days produced significant renal toxicity as indicated by a significant increase ( $\mathrm{P}$ $<0.001$ ) in blood urea, serum creatinine, and urine glucose. Further, it was associated with a significant reduction in creatinine clearance $(\mathrm{P}<0.001)$ compared with the normal control group.

In addition, administration of $300.000 \mathrm{IU} / \mathrm{kg} / \mathrm{day}$ of colistin for 7 days led to a focal tubular dilatation, interstitial edema and inflammatory cell infiltration in colistin only treated negative control group. Furthermore, we observed a significant rise in MDA level and a decline of catalase activity and reduced GSH level in renal tissue of colistin treated negative control group. These observations suggest oxidative stress as a mechanism of colistin induced renal toxicity. Oxidative stress has been reported as a cause of renal toxicity induced by many drugs including colistin. ${ }^{23}$ NSO treatment at the dose of 1 and $2 \mathrm{ml} / \mathrm{kg}$ produced dosedependent improvement in the loss in body weight compared with the negative control group. But the improvement was lesser than in the normal control group, suggesting that supplementary energy must be supplied through diet.

Similarly, NSO treatment failed to completely prevent the edema caused by colistin administration. Although NSO at the dose of $2 \mathrm{ml} / \mathrm{kg}$ significantly $(\mathrm{P}<0.001)$ decreased the edema, it still did not return to normal. This suggests prolongation of NSO treatment might completely prevent the edema. NSO treatment for seven days produced dosedependent protection in the alteration of markers of nephrotoxicity compared with the negative control group, although the protection was insignificant at a dose of $1 \mathrm{ml} / \mathrm{kg}$.

But, the NSO treatment at a dose of $2 \mathrm{ml} / \mathrm{kg}$ produced significant protection compared with the negative control group. NSO at $2 \mathrm{ml} / \mathrm{kg}$ reduced the blood urea, serum creatinine, and urine glucose by $29.22 \%, 26.32 \%$, and $19.90 \%$, respectively, and increased the creatinine clearance by $12.74 \%$. Several possible mechanisms have been proposed to explain the colistin-induced nephrotoxicity.

Colistin causes an acute tubular necrosis by increasing tubular cell permeability leading to the influx of cations, anions, and water leading to cell swelling and cell lysis. Another report suggests acute interstitial nephritis due to hypersensitivity reactions to polymixins. ${ }^{24-26}$ But, in a study by Ozkan et al., suggested oxidative damage is involved in colistin nephropathy. Colistin nephropathy was associated with an increase in iNOS and eNOS, and an increase in eNOS expression was parallel to apoptotic injury and thus necrotic damage ${ }^{27}$ In this study, oxidative stress in colistin nephropathy is confirmed by elevated MDA level and reduction in GSH and catalase activity after the treatment with colistin in the negative control group. Administration of NSO at the dose of 1 and $2 \mathrm{ml} / \mathrm{kg}$ in test groups produced dose-dependent protection against lipid peroxidation and increased the activity of catalase and the level of GSH against colistin induced oxidative stress (Table 3). The beneficial effect of NSO as evidenced by improvement in biochemical markers of nephrotoxicity and supported by improvement in histological findings in Colistin nephropathy might be due to the scavenging effect of the NSO. These findings indicate that the NSO supplementation may reduce colistin-induced nephrotoxicity.

Therefore, its suggested that the NSO modulates oxidative stress in the kidney.

\section{Funding: No funding sources}

Conflict of interest: None declared

Ethical approval: The study was approved by the Institutional Animal Ethics Committee

\section{REFERENCES}

1. Michalopoulos AS, Falagas ME. Colistin and polymyxin $\mathrm{B}$ in critical care. Crit Care Clin. 2008;24:377-91.

2. Michalopoulos AS, Tsiodras SK, Rellos Menzelopoulos S, Falagas ME. Colistin treatment in patients with ICU-acquired infections caused by multidrug resistant gram negative bacteria: the renaissance of an old antibiotic. Clin Microbiol Infect. 2005;11:115-21.

3. Falagas ME, Kasiakou SK. Colistin: the revival of polymyxins for the management of multidrug resistant gram negative bacterial infections. Clin Infect Dis. 2005;40:1333-41.

4. Spapen H, Jacobs R, Van Gorp V, Troubleyn J, Honoré PM. Renal and neurological side effects of colistin in critically ill patients. Ann Intensive Care. 2011;1(1):1-7.

5. Lim LM, Ly N, Anderson D, Yang JC, Macander L, Jarkowski A, et al. Resurgence of colistin: a review of 
resistance, toxicity, pharmacodynamics, and dosing. Pharmacother J Human Pharmacol Drug Ther. 2010;30(12):1279-91.

6. Li J, Nation RL, Turnidge JD, Milne RW, Coulthard $\mathrm{K}$, Rayner CR, et al. Colistin: the re-emerging antibiotic for multidrug-resistant Gram-negative bacterial infections. Lancet Infect Dis. 2006;6(9):589601

7. Nation RL, Li J. Colistin in the 21st century. Curr Opin Infect Dis. 2009;22(6):535.

8. Ozkan G, Ulusoy S, Orem A, Alkanat M, Mungan S, Yulug E, et al. How does colistin-induced nephropathy develop and can it be treated? Antimicrob Agents Chemother. 2013;57(8):3463-9.

9. Azad MAK, Akter J, Rogers KL, Nation RL, Velkov $\mathrm{T}$, Li J. Major pathways of polymyxin- induced apoptosis in rat kidney proximal tubular cells. Antimicrob Agents Chemother. 2015;59:2136-43.

10. Sindhi V, Gupta V, Sharma K, Bhatnagar S, Kumari R, Dhaka N. Potential applications of antioxidants - A review panel. J Pharm Res. 2013;7(9):828-35.

11. Ali BH, Blunden G. Pharmacological and toxicological properties of Nigella sativa. Phytotherapy Research. Int J Dev Pharmacol Toxicol Eva Nat Produ Derivati. 2003 Apr;17(4):299-305.

12. Ahmad A, Husain A, Mujeeb M, Khan SA, Najmi AK, Siddique NA, et al. A review on therapeutic potential of Nigella sativa: A miracle herb Asian Pac J Trop Biomed. 2013 May 1;3(5):337-52.

13. Mansour MA, Nagi MN, El-Khatib AS, Al-Bekairi AM. Effects of thymoquinone on antioxidant enzyme activities, lipid peroxidation and DT-diaphorase in different tissues of mice: a possible mechanism of action. Cell Biochem Func. 2002 Jun;20(2):143-51.

14. Salem ML. Immunomodulatory and therapeutic properties of the Nigella sativa L. seed. International immunopharmacology. 2005 Dec 1;5(13-14):174970.

15. Badary OA, Taha RA, Gamal El-Din AM, AbdelWahab MH. Thymoquinone is a potent superoxide anion scavenger. Drug and Chem Toxicol. 2003 Jan 1;26(2):87-98.

16. Yehuda S, Carasso RL. Modulation of learning, pain thresholds, and thermoregulation in the rat by preparations of free purified alpha-linolenic and linoleic acids: determination of the optimal omega 3to-omega 6 ratio. Proceedings of the National Academy of Sciences. 1993 Nov 1;90(21):10345-9.
17. Laakso P, Voutilainen P. Analysis of triacylglycerols by silver-ion high-performance liquid chromatography-atmospheric pressure chemical ionization mass spectrometry. Lipids. 1996 Dec;31(12):1311-22.

18. Russo GL. Dietary n- 6 and n- 3 polyunsaturated fatty acids: from biochemistry to clinical implications in cardiovascular prevention. Biochem Pharmacol. 2009 Mar 15;77(6):937-46.

19. Ghlissi Z, Hakim A, Mnif H, Ayadi FM, Zeghal K, Rebai $T$, et al. Evaluation of colistin nephrotoxicity administered at different doses in the rat model. Renal failure. 2013 Sep 1;35(8):1130-5.

20. Buege JA, Aust SD. [30] Microsomal lipid peroxidation. InMethods in enzymology 1978 Jan;52:302-310. Academic Press.

21. Sinha AK. Colorimetric assay of catalase. Analytical biochemistry. 1972 Jun 1;47(2):389-94.

22. Ellman GL. Tissue sulfhydryl groups. Arch Biochem Biophys 1959;82:70-7.

23. Yousef JM, Chen G, Hill PA, Nation RL, Li J. Ascorbic acid protects against the nephrotoxicity and apoptosis caused by colistin and affects its pharmacokinetics. J Antimicrob Chemother. 2012;67:452-9.

24. Mendes CAC, Burdmann EA. Polymyxins: review with emphasis on nephrotoxicity. Rev Assoc Med Bras. 2009;55(6):752-9.

25. Falagas ME, Kasiakou SK. Toxicity of polymyxins: a systematic review of the evidence from old and recent studies. Crit Care. 2006;10(1):R27.

26. Falagas ME, Fragoulis KN, Kasiakou SK, Sermaidis GJ, Michalopoulos A. Nephrotoxicity of intravenous colistin: a prospective evaluation. Int $\mathbf{J}$ Antimicrob Agents. 2005;26(6):504-7.

27. Ozkan G, Ulusoy S, Orem A, Alkanat M, Mungan S, Yulug E, et al. How does colistin-induced nephropathy develop and can it be treated? Antimicrob Agents Chemother. 2013;57(8):3463-9.

Cite this article as: Rana MA, Nadeem Arshad M, Siddiqui SS, Nasiruddin M. Study of effect of Nigella sativa on prevention of nephrotoxicity induced by colistin in experimental animals. Int $\mathbf{J}$ Basic Clin Pharmacol 2019;8:306-11. 